\title{
Impact of Discretionary Expenditures on Profitability during Recession: Evidence from Manufacturing Sector in India
}

\author{
K. S. Sujit, B. Rajesh Kumar \\ Institute of Management Technology, Dubai, UAE \\ Email: sujit@imtdubai.ac.ae, rajesh@imtdubai.ac.ae
}

Received 14 March 2016; accepted 31 May 2016; published 3 June 2016

Copyright (C) 2016 by authors and Scientific Research Publishing Inc.

This work is licensed under the Creative Commons Attribution International License (CC BY). http://creativecommons.org/licenses/by/4.0/

c) (i) Open Access

\begin{abstract}
Advertisement and R \& D expenditures are often considered as strategic variables which add value to the firm. During recession these expenses are often been compromised due to various reasons by the firms. This sometimes proves out to be costly for the firms in long run as they fail to catch up even after recession is over. Firms while taking these decisions often ignore the interaction effect of these variables with other variables in affecting profitability. This paper aims to show that Advertisement and $R \& D$ activities have moderated other variables in positively affecting performance especially during recession. Hence, firms must take into consideration the interaction effects of $R \& D$ and advertisement intensities with other important variables.
\end{abstract}

\section{Keywords}

R \& D Expenses, Advertising Expenses, Interaction Effects, Recession, Profitability

\section{Introduction}

The role of advertisement and R \& D activities are considered to be key to success in business. Often these expenditures are considered as discretionary expenses by firms during recession. As per Cambridge business dictionary it is defined as the money spent by a company on things such as advertising or development of new products, which can be reduced temporarily without affecting business. During recession firms face in hard time with contraction of sales revenue, cash flows and profits resulting in cost cutting wherever possible. Firms with the aim of cost cutting look for discretionary expenditure such as advertisement and R \& D expenses. Many believe that compromising these expenditures is costly mistakes that companies commit which deviate firms from its long-term growth path. Marketing and innovation are considered to be the most important conduct variables that 
add value and increase the profitability of firm. Peter Drucker also considered these two activities that make money for any business; everything else is cost [1]. If it is true then reducing expenditure on innovation and marketing activities is never a good idea at any point of time or in any situation. This study investigates R \& D and advertisement behavior of firms operating in India during recession and its impact on performance.

Economics fluctuation in terms of recession and boom is part of business cycle which keeps recurring over time in every economy. Fluctuation in economic activities during recession leads to changes in the behavior of the firms in the industry. During boom firms face no pressure to compromise discretionary expenditure and the focus of the firms is on the long-term growth of the firm. During recession managers are under pressure from the owners and shareholders to show higher profitability. The firms in order to show profitability among other things look for cost cutting without affecting the operations of the firm. The focus shifts from long-term growth to short-term performance leading to cut in discretionary expenditures of the firm. Discretionary expenditures are the cost that managers find it easy to eliminate or postpone. Reduction in discretionary expenditure certainly helps the firm in the short run but it derails the long-term growth of the firms. Once recession is over, firms find it hard to catch up with its long-term goal and suffer accordingly. This could lead to huge permanent realignments in the marketplace [2]. Some firms lose their market compared with the firms which keep the pace with the technological advancement.

This study aims to develop a contingent model of the effects of R \& D and advertisement intensities on firm performance in recession. Firm level contingencies such as market share, financial leverage, size of the firm along with business house affiliation moderate the effect of $\mathrm{R} \& \mathrm{D}$ and advertisement intensity in recession on firm performance. The impact could help the managers to understand the effectiveness of these value creating activities in the firm especially during recession. India being a rapidly developing country it would be interesting to understand the behavior of firms with respect to advertisement and $\mathrm{R} \& \mathrm{D}$ activities during recession.

It is often observed that firms cut functional budgets as a tactical response to economic crisis. When revenue falls, profits will fall too, unless costs are reduced by at least the amount of the contribution lost. In the context of profit maximization, when revenues fall, the intuitive short-term response would be to cut costs. However, the best strategic response would be to optimize costs rather than minimize it. In the event of economic crisis, thus R \& D costs might become an easy target for cost cutting initiatives. From a strategic perspective, it is important for a company to realize that innovation as a result of $\mathrm{R} \& \mathrm{D}$ investment would result in long-term competitive advantage. For example, Apple focused on innovation during the recession period and iPad was just the latest in a series of innovative product launches. This investment strategy during recession is considered as expenditure on innovation and market diversification. Recession is regarded as an opportunity to implement strategic change that would not have otherwise occurred. Many firms are likely to be too preoccupied with short-term survival to think about innovation and growth or may lack the resources to implement such strategies effectively.

An annual survey of 1000 global businesses by consultants Booz \& Company finds that the world's largest corporate R \& D spenders finds that most companies had carried on innovation programs despite the recession. Marketing have also been a prime target for cost savings during the recession period. Companies cut advertising expenses during recession period. It is very important for companies to maintain strong brand presence using advertising efforts. The economic downturn has thrown up challenges for companies to rethink the relationship between short term costs and long term profits. The focus would be not about how costs can be minimized, but about how to maximize the returns from the costs. In difficult economic times, firms often adopt retrenchment strategies to deal with recessionary conditions. This common strategy involves cutting operating costs and divestment of non-core assets. Examples include divestment of businesses, closure of plants, reduction in employment, cuts on wide range of expenditure which includes R \& D, marketing and training.

\section{Literature Review}

There is a large volume of literature explaining the relationship between performance indicators with discretionary expenditure of the firm. Advertisement and R \& D expenditure are the most popular discretionary expenditures used by many scholars in their studies. Firms change their resource deployment patterns in response to environmental changes [3]-[5]. The impact of recession on these discretionary expenditures is however mixed. During an economic downturn, some firms might see the changed economic environment as an opportunity and respond by increasing their discretionary expenditures, whereas other firms might perceive it as a threat and respond by conserving resources [6]. 
During recession the firms suffer from liquidity crunch and those firms investing in R \& D activities can find it difficult to fund. Despite liquidity crunch firms keep funding its R \& D activities due to fear of lagging behind on the long-term technological advancements [7]. In order to fund R \& D the firms squeeze other budgets [8]. On the other hand [9] showed that firms in general cut their R \& D activities irrespective of liquidity. During slowdown of economic activities, market shrinks and the focus normally shifts from long-term growth to short term growth. As a result pressure may be exerted on managers to sacrifice R \& D to maintain short-term earnings growth [10]-[12].

As the returns on $\mathrm{R} \& \mathrm{D}$ is more uncertain than advertisement, hence there are possibilities that a firm may reduce expenditure on $\mathrm{R} \& \mathrm{D}$ and increase on advertisement expenditure [6] [13] [14]. There is also the possibility that during recession the R \& D activities may increase so that the recovery would be fast. The study by [15] reports that increases in $\mathrm{R} \& \mathrm{D}$ spending in recessions increase firm profits and intangible value.

Similarly advertisement expenditure is also considered to be luxury during recession and the budget is cut to improve liquidity. Studies like [16]-[18] commented that it should be cut. On the other hand [19] commented that lower advertisement during recession creates emptiness in the market and it would be advantageous for the firms to exploit more through advertisement. Advertisement provides an unusual opportunity to differentiate and gain more market during recession. The result however, is mixed with [20] found increase in advertisement increases the profit. Study by [21] reported that cutting advertising in recessions does not affect profits. Whereas [22] showed that during recession consumers also have liquidity crunch and switch to the product with lower cost. This would reduce the returns on advertisement.

Some attributed difference in advertisement and its variations is linked to the nature of product. Advertising as a percentage of sales is likely to be higher for consumer product organizations than for manufacturing product organizations [23]. On the other hand, manufacturing products are typically sold to a few large consumers that are often geographically concentrated and most of the business-to-business marketing budget is spent on the personal selling effort with advertising supporting and supplementing that effort [24].

As there are mixed findings in literature which can be attributed to firm-level, industry level and all other internal and external environment faced by the firms. Some firms have reasons to increase and some to decrease discretionary expenditure. This study is an attempt to evaluate the impact of R \& D and Advertisement intensities as discretionary on profitability. In this attempt both direct and indirect impacts are assessed. It also captures firms' behavior during recession. This study is also an attempt to combine all possible attributes by including firm level, industry level and group level contingencies to model the impact of R \& D and advertisement intensities on performance during recession as compared to non-recessionary period. It is evident that bad decisions during recessions are often irrecoverable and damageable. This study would help the managers to see the difference in the impacts which ultimately helps them to take better decisions.

\section{Hypothesis}

The contingency approach to theory building focuses on key situational relationships which are backed by theory and an alternative to searching for universal principles. Contingency approach is increasingly used in management discipline due to interrelations among different firm level, industry level and environment level variables. Study by [25] [26]; and more recently by [7] studied the effects of a firm's actions on its performance which are moderated by characteristics of both firm and the market place in which firm operates. In their study market share, financial leverage and product market profile moderated the reward for R \& D and advertisement spending in recession. In our study we have incorporated business house affiliation as an important moderator in Indian scenario.

\section{Moderating Effect of Market Share in Recessions:}

Following traditional SCP framework proposed by [27] and [28] firms with higher market share enjoy significant market power which ultimately is reflected in its performance. Firms with higher market share could achieve economies of scale in its R \& D program and have greater market power to push the products in the depressed market.

H1: During recession, the profit impact of a firms $R \& D$ spending increases as its market share increases.

Firms with higher market share have high level of consumer awareness and market penetration [29]. During recession when consumers are reluctant to buy products, spending on advertisement may not be that rewarding. Consumers may switch to the firms with low profit margin or postpone their spending. It may not be profitable for high market share firm to increase expenditure on advertisement. 
H2: During recession, the profit impact of a firms Advertisement spending decreases as its market share increases.

\section{Moderating Effect of Financial Leverage in Recessions:}

Financial leverage is the extent to which firm uses its debt to finance its assets. Firms with higher financial leverage (high debt assets ratio) might struggle to get fund during recession and limiting its strategic options [30]. In general, financial leverage is negatively related to both $\mathrm{R} \& \mathrm{D}$ and advertisement intensities.

However, high financial leverage firms increase R \& D in recession indicates R \& D program to be crucial for its competitive advantage and the outcome of it would beat the cost of capital resulting from higher financial leverage.

Similarly, a firm with higher financial leverage increases advertisement expenses during recession clearly indicates that it has something important to communicate to the consumers and the products it sells is differentiated. This results in increased sales and profits for its advertisement spending during recession. Based on these arguments the study proposes $\mathrm{H} 3$ and $\mathrm{H} 4$.

H3: During recession, the profit impact of a firms $R \& D$ spending increases as its financial leverage increases.

H4: During recession, the profit impact of a firms advertisement spending increases as its financial leverage increases.

\section{Moderating Effect of Business House Affiliation in Recessions:}

In emerging market business groups play an important role especially in India because of its ability to diversify at lower cost than the independent firm [31]. Group affiliated firm with its access to resources would not compromise in reducing discretionary expenses during recession as compared to non-group affiliated firm. There could also be certain costs associated with the group affiliated firms. Common family ownership can result in conflict and misallocation of resources from profit making firms to a loss making firm within the group. If this is the case, then discretionary expenses would be compromised.

H5: During recession, the profit impact of a firms $R \& D$ spending increases if it is affiliated to business houses.

H6: During recession, the profit impact of a firms Advertisement spending increases if it is affiliated to business houses.

\section{Moderating Effect of Size in Recessions:}

Size of the firm is always used as an important variable which could influence strategic decisions on $\mathrm{R} \& \mathrm{D}$ and Advertisement expenses. The study by [32] suggested that in a mature capitalist economy, large firms generate disproportionately large share of society's technological advancements. This view appears to be true in case of emerging markets as well where large firms secure finance for risky R \& D projects easily than the small sized firm. Firm size may affect R \& D performance through scale economies or diseconomies [33]. There is the possibility of it to be collinear with the diversification [34] leading to higher spending on R \& D activities. Similarly, large firms with significant portfolio of products and services tend to spend more on advertisement.

In a competitive market large firms often spend more on these value creating activities for expansion by investing on new product development. Both $\mathrm{R} \& \mathrm{D}$ and advertisement expenditure is likely to go up as size of the firm grows. If there are size advantages in $\mathrm{R} \& \mathrm{D}$ and advertisement, the amount of money spent on these expenditures during recession will go up and may not be compromised.

H7: During recession, the profit impact of a firms $R \& D$ spending increases as size of the firm is large.

H8: During recession, the profit impact of a firms $A D V$ spending increases as size of the firm is large.

\section{Data and Model}

The study develops a contingent model of the effects of R \& D and advertisement intensities on firm performance in recessions. Then the study empirically tests the impact of contingent factors such as market share, financial leverage and business house affiliation significantly changes the effects of $R \& D$ and advertisement intensities on firms' performance during recession.

In order to capture the impact of a particular period, the study uses year dummy. In this study the main variable that impacts profitability are R \& D and Advertisement expenditure which in turns contingent upon other factors. Using the estimates of contingent effects, the study computed the marginal effects of R \& D and advertisement on profitability. Marginal effects are useful to understand if firms spend differently based on changes in the main dependent variable i.e. profitability.

The model to capture R \& D behavior during different years representing contraction and expansion is as follows: 


$$
\text { profit }=w_{0}+w_{1} X+w_{2} \text { Year } \times X+w_{3} \text { Year }
$$

In Equation (1), $w_{1}$ captures the impact of $X$ ( $\mathrm{R} \& \mathrm{D}$ and advertisement) on profit whereas $w_{2}$ captures the impact of $X$ in recession. The main impact of designated recession is captured by $w_{3}$. It is assumed that the relationship between profit and $X$ is influenced by a contingency $Z_{1}$ which is financial leverage, size of the firm, business house affiliation and market share. In that case $w_{1}$ and $w_{2}$ will be affected by $Z_{1}$. In order to accommodate this, the study has taken Equations (2) and (3) as specified below.

$$
\begin{aligned}
& w_{1}=a_{01}+a_{11} Z_{1} \\
& w_{2}=b_{02}+b_{12} Z_{1}
\end{aligned}
$$

Incorporating Equations (2) and (3) in Equation (1) by controlling the main effect of $Z_{1}$, the modified equation can be written as

$$
\text { prof }=w_{0}+\left(a_{01}+a_{11} Z_{1}\right) X+\left(b_{02}+b_{12} Z_{1}\right) \text { Year } \times X+w_{3} \text { Year }+w_{4} Z_{1}
$$

From Equation (4) marginal effect of $X$ on $Y$ can be easily calculated

$$
\frac{\mathrm{d}(\text { prof })}{\mathrm{d}(X)}=\left(a_{01}+a_{11} Z_{1}\right)+\left(b_{02}+b_{12} Z_{1}\right) \text { Year }
$$

The marginal effect measures the effectiveness of changes in $X$ with respect to profitability by taking into accounts both $Z_{1}$ and year (proxy for recession). During recession the year dummy takes value one and hence the marginal effect of $X$ on profitability is represented by $\left(a_{01}+a_{11} Z_{1}\right)+\left(b_{02}+b_{12} Z_{1}\right)$. For other years the marginal effect is $\left(a_{01}+a_{11} Z_{1}\right)$.

It is important to note here that the coefficient $b_{12}$ measures the influence of $Z_{1}$ on the relationship between profitability and $X$ in the recession years (a three way interactions). In non-recession years, the influence of $X_{1}$ on the relationship between profitability can be captured by coefficient $\alpha_{11}$ (two way interaction). A positive sign of the coefficient $b_{12}$ indicates higher $Z_{1}$ increases the effect of $X$ on profitability during recession.

\subsection{Model Specification}

Both advertisement intensity and R \& D intensity are taken to capture discretionary expenditure of the firm. In case of India there are many firms which only spend on advertisement and for technological development they prefer buying or royalty payment route. Keeping this in mind, the study uses three models. Model- 1 captures the impact of R \& D on profitability, Model-2 captures the impact of advertisement on profitability and Model-3 captures the combined effect of both.

Model-1

$$
\begin{aligned}
\text { profit }_{i t}= & w_{0}+\left(a_{1}+a_{2} M S_{i t-1}\right) R \& D_{i t-1}+\left(a_{3}+a_{4} \text { finlev }_{i t}\right) R \& D_{i t-1}+\left(a_{5}+a_{6} B H A\right) R \& D_{i t-1} \\
& +\left(b_{1}+b_{2} M S_{i t-1}\right) \text { Year } \times R \& D_{i t-1}+\left(b_{3}+b_{4} \text { finlev }_{i t}\right) \text { Year } \times R \& D_{i t-1} \\
& +\left(b_{5}+b_{6} B H A_{i t}\right) \text { Year } \times R \& D_{i t-1}+w_{3} \text { Year }+w_{4} M S_{i t-1}+w_{5} \text { finlev }_{i t}+w_{6} B H A+\varepsilon_{i t}
\end{aligned}
$$

This can be re arranged as

$$
\begin{aligned}
\text { Profit }_{i t}= & w_{0}+\alpha_{0} R \& D_{i t-1}+a_{2} M S_{i t-1} R \& D_{i t-1}+a_{4} \text { finlev }_{i t} R \& D_{i t-1}+a_{6} B H A R \& D_{i t-1} \\
& +\beta_{0} \text { YearR \& } D_{i t-1}+b_{2} M S_{i t-1} \text { YearR } \& D_{i t-1}+b_{4} \text { finlev }_{i t}{\text { YearR } \& D_{i t-1}} \\
& +b_{6} \text { BHA YearR \& } D_{i t-1}+w_{3} \text { Year }+w_{4} M S_{i t-1}+w_{5} \text { finlev }_{i t}+w_{6} B H A+\varepsilon_{i t}
\end{aligned}
$$

Similarly model can be developed for advertisement as well

Model-2

$$
\begin{aligned}
\text { Profit }_{i t}= & w_{0}+\alpha_{0} A D V_{i t-1}+a_{2} M S_{i t-1} A D V_{i t-1}+a_{4} \text { finlev }_{i t} A{ } V_{i t-1}+a_{6} B H A A D V_{i t-1} \\
& +\beta_{0} \text { YearADV }_{i t-1}+b_{2} M S_{i t-1} \text { YearADV }_{i t-1}+b_{4} \text { finlev }_{i t}{\text { Year } A D V_{i t-1}} \\
& +b_{6} \text { BHA YearADV } V_{i t-1}+w_{3} \text { Year }+w_{4} M S_{i t-1}+w_{5} \text { finlev }_{i t}+w_{6} B H A+\varepsilon_{i t}
\end{aligned}
$$

Model-3 combines both advertisement intensity and $\mathrm{R} \& \mathrm{D}$ intensity together in influencing the profitability. 
where;

$R \& D_{i t-1}=\mathrm{R} \& \mathrm{D}$ intensity( $\mathrm{R} \& \mathrm{D}$ expenditure/Sales revenue) of firm $i$ in the year $t-1$.

$A D V_{i t-1}=$ Advertisement intensity (Advertisement expenditure/Sales revenue) of firm $i$ in the year $t-1$.

$M S_{i t-1}=$ Market share of the firm $i$ in the year $t-1$ (lagged by one year).

finlev $_{i t}=$ financial leverage is the ratio of debt to assets of the firm $i$ in year $t$ (debt/assets).

Profit $_{i t}=$ Profitability (profit after tax/sales revenue) of the firm $i$ in the year $t$ (dependent variable).

Size $_{i t}=$ Size of the firm which is taken as natural logarithm of assets.

Year $=1$ if the year is recession year, and 0 if otherwise.

$B H A=$ Business House Affiliation dummy. For example it takes value one if the firm is affiliated to a business house or else zero.

$\varepsilon_{i t}=$ The error term includes autoregressive and random unobserved factors.

$\alpha_{0}=\left(a_{1}+a_{3}+a_{5}\right)$ : This coefficient captures the main effect of profitability on $\mathrm{R} \& \mathrm{D}$ in non-recessionary year.

$\beta_{0}=\left(b_{1}+b_{3}+b_{5}\right)$ : This coefficient captures the main effect of profitability on $\mathrm{R} \& \mathrm{D}$ in recessionary year.

$a_{k}=(\mathrm{k}=2,4,6)$ : Captures two way contingent effect on R \& D.

$b_{k}=(k=2,4,6)$ : Captures three way contingent effect on the recession year.

$w_{k}=(k=3$ to 6$)$ : The coefficients capturing the main effects of recession, market share, leverage and business house affiliation.

\subsection{Data}

The study collected required data form Prowess database provided by Center for Monitoring Indian Economy (CMIE), Mumbai, India. Prowess is the largest database on the performance of Indian companies. It comprises data (both financial and non-financial) on more than 22,000 Indian companies. The coverage includes public, private, co-operative and joint sector companies, listed or otherwise. The database includes a major part of large manufacturing firms and a relatively small proportion of the small or medium firms. It reports two R \& D figures i.e. R \& D on capital account and R \& D on current account. Total R \& D expenditure is calculated by adding both.

Many times, companies do not disclose revenue expenditure on research and development separately because it is a relatively very small amount. As a mandatory requirement, companies are required to disclose this information as part of report of Board of Directors which helps in estimating total research and development expenses incurred by a company.

For this study the final data set is prepared in the following ways. Those firms which reported zero sales figure are dropped from the database. Final sample consists of 3439 cross sections from 26 industries for the time period 2000 to 2012 are included in panel data. It is also important to mention that in some cases the data for all the years are not there hence it is unbalanced panel. Combining all the time series and cross section there are 25,534 observations included in the estimation.

CMIE database classifies business houses into the "Top-50 business houses", "Large business houses other than the top fifty”, "Private foreign business houses” and other business houses. In order to represent Indian business houses affiliated firms’ top-50 business houses is clubbed into large business houses and other business houses. Business house dummy takes the value one if the firm is affiliated to a business house or else zero.

These firms by no means represent the whole manufacturing sector of India but the availability of firm level data restricted the study to confine with the existing sample which remains the limitation of the study.

\subsection{Choosing Recession Years}

The widely-accepted, but a narrow definition of a recession is two successive quarters of negative growth in gross domestic product (GDP). The present study has taken recession as contraction in the economy over a whole year. This study relied on two sources to identify the recession years. The first source comes from OECD Composite Leading Indicator which uses the index of industrial production (IIP) as a reference series, which is available on a monthly basis ${ }^{1}$. According to composite leading indicator the year 2000, 2001, 2002, 2008, 2011

${ }^{1}$ OECD Composite Leading Indicators, “Composite Leading Indicators: Reference Turning Points and Component Series”, www.oecd.org/std/cli. 
and 2012 are recessionary periods. Composite Leading Indicators however, have a tendency to turn earlier than the business cycle. In order to verify this study used GDP real growth rate on an annual basis adjusted for inflation. As plotted in Figure 1 contractions in business cycle period can be seen in the year 2001, 2003, 2008 and 2011. According to IMF data, in 2012, India's real gross domestic product growth was at about 4.5 percent which is lower as compared to the previous year ${ }^{2}$. Hence, the year 2012 is also taken as a recessionary year. For this study 2001, 2003, 2008, 2011 and 2012.

\section{Empirical Result}

Descriptive statistics gives an overall understanding of the nature of data used in model building. It also provides the distribution and the range of the each variable used in the model. The descriptive statistics, in Table 1 , shows preliminary understanding of the unbalanced panel consists of 2534 observations. The mean profitability (PAT/Sales) is around -0.073 percent with standard deviation of 1.65 . This shows that many firms are reporting loss for the sample period and standard deviation is not high. The mean R \& D intensity (including both current account and capital account) is around 0.5 percent with low standard deviation of 0.02 which shows less variability in R \& D intensity. Average advertisement intensity (Advertisement expenses/Sales) is around 0.9 percent with standard deviation 0.036. This indicates Indian firms on an average spend higher on advertisement than $\mathrm{R}$ \& $\mathrm{D}$ as a percentage of sales. The standard deviation is higher in advertisement indicating more variations in advertisement intensity as compared to R \& D intensity but in both the cases the value of standard deviation is less indicating less deviation from the mean. On the other hand, mean market share in the sample data is around one percent, whereas the mean of financial leverage (debt/assets) is around 0.45 percent. Size of the firm which is natural logarithm of assets is shows mean of 6 and standard deviation of 1.88. Positive values of skewness suggest the distribution of variables is positively skewed except for profitability. The calculated Jarque-Bera statistics for all the variables are very high and p-value suggests that the sample is not normally distributed. Similar observations are reported by [35] as well where the distribution is known to be skewed towards larger values, with a large portion of non-R \& D-performing firms.

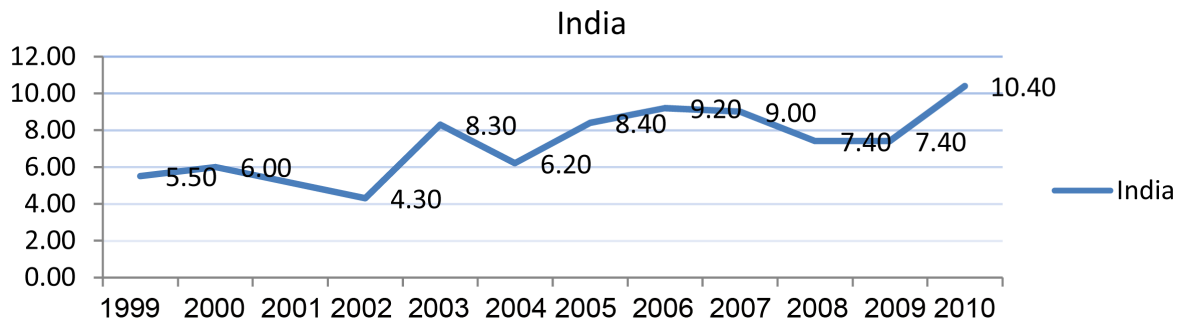

Figure 1. GDP-real growth rate. Source: http://www.indexmundi.com.

Table 1. Descriptive statistics.

\begin{tabular}{|c|c|c|c|c|c|c|}
\hline & Profitability & R \& D Intensity & Advertisement Intensity & Financial Leverage & Market Share & Size \\
\hline Mean & -0.073 & 0.005 & 0.009 & 0.451 & 0.010 & 6.208 \\
\hline Median & 0.026 & 0 & 0.001 & 0.339 & 0.001 & 6.143 \\
\hline Std. Dev. & 1.65 & 0.02 & 0.03 & 1.26 & 0.04 & 1.88 \\
\hline Skewness & -22.39 & 12.01 & 14.68 & 28.29 & 10.72 & 0.18 \\
\hline Kurtosis & 886.32 & 234.54 & 366.81 & 1135.21 & 165.44 & 3.53 \\
\hline Jarque-Bera & $8.32 \mathrm{E}+08$ & $5.77 \mathrm{E}+07$ & $1.42 \mathrm{E}+08$ & $1.37 \mathrm{E}+09$ & $28,561,919$ & $4.37 \mathrm{E}+02$ \\
\hline Probability & 0 & 0 & 0 & 0 & 0 & 0 \\
\hline
\end{tabular}

${ }^{2}$ http://www.statista.com/statistics/14564/growth-of-indias-gross-domestic-product/. 
After the preliminary understanding of the data the study proceeded with the estimation the contingent model. As discussed above the models are estimated using three models with profitability as dependent variable. Model-1 and Model-2 are estimated by taking Advertisement intensity and R \& D intensity separately. Model-3 is estimated to see the combined effect of advertisement and R \& D intensity in recession. In Indian manufacturing sectors there are firms which don't spend on R \& D activities as they buy readymade machineries and only spend on advertisement. For these firms advertisement is important and hence Model-2 is designed to capture these firms. In some cases both R \& D and Advertisement is used as strategic variables for them a combined model would do justices.

Ordinary least square method is used for panel data. When the number of observations is large multicollinearity is unlikely to be high. The correlation matrix in Table 2 shows that correlation among independent variables is not high. Further to reconfirm, variance inflation factor for the model is examined and found them to be less than five, suggesting that multi collinearity is unlikely to be a threat to the validity of the results.

The results presented in Table 3 and Table 4 show that in all the models data fits well with highly significant F-value and $\mathrm{R}^{2}$ is not interpretable for this model [36] and [7]. The hypotheses are tested by assessing the statistical significance of the related three way interactions effects.

Table 2. Correlation matrix.

\begin{tabular}{ccccccc}
\hline & Profitability & R \& D & Advertisement & Market Share & Financial Leverage & Size \\
\hline Profitability & 1 & -0.0374 & 0.0824 & 0.0003 & -0.055 & 0.0001 \\
R \& D & -0.0374 & 1 & -0.0088 & 0.0201 & 0.0085 & 0.0037 \\
Advertisement & 0.0824 & -0.0088 & 1 & 0.0253 & 1 & -0.0362 \\
Market Share & 0.0003 & 0.0201 & 0.0253 & 0.068 & 1 \\
Financial Leverage & -0.055 & 0.0085 & 0.0129 & -0.0362 & -0.0278 \\
Size & 0.0001 & 0.0037 & -0.068 & 0.3739 & -0.0278 \\
\hline
\end{tabular}

Table 3. Effects of R \& D and advertisement in recession.

\begin{tabular}{|c|c|c|c|}
\hline Effects & $\begin{array}{l}\text { Model-1: } \\
\text { R \& D in } \\
\text { Recession }\end{array}$ & Effects & $\begin{array}{c}\text { Model-2: } \\
\text { Advertisement } \\
\text { in Recession }\end{array}$ \\
\hline Three Way Interactions & \multicolumn{3}{|c|}{ Three Way Interactions } \\
\hline R \& D × Recession $\times$ Market Share & $1.188(1.83)^{* * *}$ & Advertisement $\times$ Recession $\times$ Market Share & $-0.055(0.323)$ \\
\hline R \& D × Recession $\times$ Financial Leverage & $7.364(16.35)^{*}$ & Advertisement $\times$ Recession $\times$ Financial Leverage & $4.698(4.085)^{*}$ \\
\hline R \& D $\times$ Recession $\times$ Business House Affiliation & $3.267(1.406)$ & Advertisement $\times$ Recession $\times$ Business House Affiliation & $-5.766(3.58)^{*}$ \\
\hline R \& D $\times$ Recession $\times$ Market Size & $-2.925(4.024)^{*}$ & Advertisement $\times$ Recession $\times$ Market Size & $0.292(0.88)$ \\
\hline Two Way Interactions & \multicolumn{3}{|c|}{ Two Way Interactions } \\
\hline R \& D × Recession & $15.36(3.68)^{*}$ & Advertisement $\times$ Recession & $1.452(0.81)$ \\
\hline R \& D × Market Share & $0.302(0.714)$ & Advertisement $\times$ Market Share & $0.117(0.916)$ \\
\hline R \& D × Financial Leverage & $-12.096(31.28)$ & Advertisement $\times$ financial Leverage & $10.56(12.56)^{*}$ \\
\hline R \& D × Business House Affiliation & $-0.172(0.116)$ & Advertisement $\times$ Business House Affiliation & $0.075(0.66)$ \\
\hline R \& D × Market Size & $-0.302(0.887)$ & Advertisement $\times$ Market Size & $2.9372(1.101)$ \\
\hline Control Variables & \multicolumn{3}{|c|}{ Control Variables } \\
\hline Recession & $-0.552(2.646)^{*}$ & Recession & $-0.042(1.95)^{* * *}$ \\
\hline Market Share & $0.0012(0.369)$ & Market Share & $0.0034(0.916)$ \\
\hline Financial Leverage & $-0.294(36.10)^{*}$ & Financial Leverage & $-0.377(42.36)^{*}$ \\
\hline Business House Affiliation & $-0.020(0.884)$ & Business House Affiliation & 0.009 (0.398) \\
\hline Market Size & $0.003(0.496)$ & Market Size & $-0.0034(0.916)$ \\
\hline R \& D & $4.108(2.206)^{* *}$ & Advertisement & $-4.749(3.62)^{*}$ \\
\hline Constant & $0.092(2.34)^{* *}$ & Constant & $0.154(3.68)^{*}$ \\
\hline Observations & 20019 & Observations & 20030 \\
\hline Overall F Value ( $p$-Value) & $8.61(0.00)$ & Overall F value ( $p$-value) & $6.59(0.00)$ \\
\hline R Square & 0.14 & & 0.08 \\
\hline
\end{tabular}


Table 4. Combined effects of R \& D and advertisement in recession.

Effects

R \& D $\times$ Recession $\times$ Market Share

Advertisement $\times$ Recession $\times$ Market Share

$\mathrm{R} \& \mathrm{D} \times$ Recession $\times$ Financial Leverage

Advertisement $\times$ Recession $\times$ Financial Leverage

R \& D × Recession $\times$ Business House Affiliation

Advertisement $\times$ Recession $\times$ Business House Affiliation

R \& D $\times$ Recession $\times$ Market Size

Advertisement $\times$ Recession $\times$ Market Size

\section{Two Way Interactions}

$\mathrm{R} \& \mathrm{D} \times$ Recession

Advertisement $\times$ Recession

R \& D × Market Share

Advertisement $\times$ Market Share

$\mathrm{R} \& \mathrm{D} \times$ financial Leverage

Advertisement $\times$ Financial Leverage

R \& D $\times$ Business House Affiliation

Advertisement $\times$ Business House Affiliation

R \& D × Market Size

Advertisement $\times$ Market Size

\section{Control Variables}

Recession

Market Share

Financial Leverage

Business House Affiliation

Market Size

Advertisement

R \& D

Constant

Observations

Overall F Value (p-value)
Combined effects of

R \& D and

Advertisement in Recession

$$
\begin{aligned}
& 1.192(2.67)^{*} \\
& -0.106(0.626) \\
& 7.380(16.46)^{*} \\
& -4.579(4.129)^{*} \\
& 4.17(1.79)^{* * *} \\
& -6.093(3.915)^{*} \\
& -2.984(4.10)^{*} \\
& 0.349(1.089)
\end{aligned}
$$

$15.413(3.704)^{*}$

$1.361(0.793)$

0.297 (0.695)

$0.146(1.165)$

$-12.016(31.22)^{*}$

$9.79(12.075)^{*}$

$-0.562(0.379)$

$0.338(0.312)$

$-0.288(0.849)$

$-0.066(0.295)$

$-0.0546$

$0.00001(0.005)$

$-0.334(38.54)$

$-0.003(0.147)$

0.003 (0.589)

-4.274 (3.337)

$4.104(2.212)^{* *}$

$0.11(2.67)^{*}$

20019

140.67

0.149 


\section{Contingent Effect of R \& D \& Advertisement Intensities in Recession}

As hypothesized $\mathrm{H} 1$ and $\mathrm{H} 2$, the interaction between R \& D in recession and market share on profit is positive and significant at 10 percent level, on the other hand Advertisement intensity in recession and market share on profit is negative and not significant. This shows that R \& D interaction on firms with large market share is contributing in higher profitability. Similar results are also confirmed in combined effect model mentioned in Table 4.

With respect to hypotheses $\mathrm{H} 3$ and $\mathrm{H} 4$, the interaction between financial leverage on profit and $\mathrm{R} \& \mathrm{D}$ in recession turned out to be positive and significant in Model-1 \& 2. In combined model advertisement interaction is negative and significant. This shows that in presence of $\mathrm{R} \& \mathrm{D}$, advertisement interaction is negative. Firms with high debt compromise on advertisement during recession rather than $\mathrm{R} \& \mathrm{D}$.

Interaction effect of R \& D and advertisement intensities with business house affiliation on profitability (H5 and H6) shows that during recession higher spending on advertisement negatively affecting profitability. R \& D contributes positively but turned out to be not significant in model-1 but it is significant in model-3. It is clear that business houses in India compromise on advertisement as the effectiveness of advertisement comes down during recession.

Contrary to the hypotheses H7, the interaction of R \& D with size of the firm in recession on profitability is negatively related to profitability. Large firms spending on R \& D are not having size advantage during recession as a result it affects negatively. Whereas the hypothesis (H8), interaction effect of advertisement in recession and size of the firm on profitability is not significant in both the models.

\section{Conclusions}

The importance of R \& D and advertisement expenditure in influencing profitability is well known and confirmed by previous studies. Evidence on the behavior of the firms during recession is difficult to understand as firms behave differently. Difference is that behavior ultimately reflects on discretionary expenditure. This study shows that difference in discretionary behavior during recession can be explained based on the impacts of advertisement and R \& D on performance, sometimes directly and sometimes indirectly in terms of its interactions with other variables. While interacting, it moderates the impact on performance. Using contingency model approach this study concludes that in case of Indian companies R \& D's interactions with market share, financial leverage and business affiliations turned out to positively influence profitability during recession. In the presence of interactions of R \& D intensity in combined model most of the interactions of advertisement intensities negatively contribute to profitability during recession. This brings us to the conclusion that R \& D interactions are more significant than the interactions of advertisement during recession. There are many firms spending only on advertisement which could draw conclusions from Model-2. High financial leveraged firms are under pressure to show performance during recession and hence increase advertisement. Whereas business houses reduce their advertisement as the brand building is not a concern to them by virtue of their strong brand presence in the market. For the firms investing only on R \& D during recession, size of the firm's interaction with R \& D intensity is negative indicating consolidation during recession by the firms. All other interactions turned out to positively contributing to profitability.

Managerial Implications: Based on the finding of this study it is clear that there cannot be a single policy for the firm behavior; firms react differently during recession. Moderating effects are important especially during recession and managers must evaluate the interactions before taking a call on compromising discretionary expenses. This study shows that most of the three ways that interaction hypothesized in the above study turned out to be significant. This may help the managers to first analyze the interactions with respect to their industry and then take a decision on R \& D and advertisement expenses. This study can be extended by focusing on industry-wise interactions which could add more lights for the managers to take a call during recession on $\mathrm{R} \& \mathrm{D}$ and advertisement.

\section{References}

[1] Drucker, P. (1954) What Is a Business? In: The Practice of Management, Harper and Row, New York.

[2] Nishimura, K.G., Takanobu, N. and Kozo, K. (2005) Does the Natural Selection Mechanism Still Work in Severe Recessions? Examination of the Japanese Economy in the 1990s. Journal of Economic Behavior and Organizations, 58, 53-78. http://dx.doi.org/10.1016/j.jebo.2004.03.008 
[3] Miller, D. (1987) The Structural and Environmental Correlates of Business Strategy. Strategic Management Journal, 8, 55-76. http://dx.doi.org/10.1002/smj.4250080106

[4] Miller, D. and Friesen, P.H. (1983) Strategy-Making and Environment: The Third Link. Strategic Management Journal, 4, 221-235. http://dx.doi.org/10.1002/smj.4250040304

[5] Weick, K.E. (1979) The Social Psychology of Organizing. Addison-Wesley, Reading.

[6] Surinder, T. and Ahmed, E. (2010) Financial Markets and Marketing the Tradeoff between R \& D and Advertising During an Economic Downturn. Journal of Advertising Research, 50, 50-56. http://dx.doi.org/10.2501/S0021849910091178

[7] Raji, S., Gary, L.L. and Shrihari, S. (2011) Should Firms Spend More on Research and Development and Advertising During Recessions? Journal of Marketing, 75, 49-65. http://dx.doi.org/10.1509/jmkg.75.3.49

[8] Worthen, B. (2009) Juniper Chief Faces Dilemma on R \& D. The Wall Street Journal, 24, B1.

[9] Barlevy, G. (2005) Why Don’t Recessions Encourage More R \& D Spending? Chicago Fed Letter, No. 220, 1-4.

[10] Drucker, P. (1986) A Crisis of Capitalism. Wall Street Journal, 30, 30-31.

[11] Jacobs, M. (1991) Short-Term America: The Causes and Cures of Our Business Myopia. Harvard Business School Press, Boston.

[12] Porter, M. (1992) Capital Choices: Changing the Way America Invests in Industry. Council on Competitiveness/Harvard Business School, Boston.

[13] Kessides, I. (1990) The Persistence of Profits in the U.S. Manufacturing Industries. In: Mueller, D., Ed., In the Dynamics of Company Profits, Cambridge University Press, Cambridge. http://dx.doi.org/10.1017/CBO9780511664724.005

[14] Mueller, D.C. (1990) The Dynamics of Company Profits. Cambridge University Press, Cambridge. http://dx.doi.org/10.1017/CBO9780511664724

[15] Graham, R. and Kristina, F. (2008) The Earnings Effects of Advertising Expenditures During Recessions. American Association of Advertising Agencies, New York.

[16] Clark, S. (2008) Marketing during a Recession? Get the Wind at Your Back. http://www.buzzmaven.com/2008/01/marketing-during-a-recession-get-the-wind-at-your-back.html

[17] Welch, J. and Suzy, W. (2008) Resolutions for the Recession. Business Week, 30 December.

[18] Biel, A.L. and King, S. (1990) Options and Opportunities for Consumer Businesses: Advertising during a Recession. The WPP Center for Research and Development, Dublin.

[19] Scanlon, J. (2009) Is Recession the Time to Boost Ad Spending? Business Week, 1 May.

[20] Kamber, T. (2002) The Brand Manager’s Dilemma: Understanding How Advertising Expenditures Affect Sales Growth during a Recession. Journal of Brand Management, 10, 106-120. http://dx.doi.org/10.1057/palgrave.bm.2540109

[21] Kijewski, V. (1982) Media Advertising When Your Market Is in a Recession. Cahners Advertising Research Report, Strategic Planning Institute, No. 2000.7, Washington St, Newton.

[22] Lamey, L., Deleersnyder, B., Dekimpe, M.G. and Steenkamp, J.-B.E.M. (2007) How Business Cycles Contribute to Private-Label Success: Evidence from the United States and Europe. Journal of Marketing, 71, 1-15. http://dx.doi.org/10.1509/jmkg.71.1.1

[23] Farris, P.W. and Buzzell, R.D. (1979) Why Advertising and Promotional Costs Vary: Some Cross-Sectional Analyses. Journal of Marketing, 43, 112-122. http://dx.doi.org/10.2307/1250277

[24] Johnston, W.J. (1994) The Importance of Advertising and the Relative Lack of Research. Journal of Business and Manufacturing Marketing, 9, 3-4.

[25] Zeithaml, V.A., Varadarajan, P.R. and Zeithaml, C.P. (1988) The Contingency Approach: Its Foundations and Relevance to Theory Building and Research in Marketing. European Journal of Marketing, 22, 37-64. http://dx.doi.org/10.1108/EUM0000000005291

[26] Srinivasana, R., Rangaswamy, A. and Lilien, G.L. (2005) Turning Adversity into Advantage: Does Proactive Marketing during a Recession Pay Off? International Journal of Research in Marketing, 22, 109-125. http://dx.doi.org/10.1016/j.ijresmar.2004.05.002

[27] Mason, E.S. (1939) Price and Production Policies of Large Scale Enterprises. The American Economic Review, 29, 61-74.

[28] Bain, J.S. (1951) Relation of Profit Rates to Manufacturing Industry Concentration American Manufacturing, 19361940. The Quarterly Journal of Economics, 65, 293-324. http://dx.doi.org/10.2307/1882217 
[29] Bloom, P.N. and Kotler, P. (1975) Strategies for High Market-Share Firms. Harvard Business Review, 53, 63-72.

[30] Grewal, R. and Tansuhaj, P. (2001) Building Organizational Capabilities for Managing Economic Crisis: The Role of Market Orientation and Strategic Flexibility. Journal of Marketing, 65, 67-80. http://dx.doi.org/10.1509/jmkg.65.2.67.18259

[31] Khanna, T. and Rivkin, J.W. (2001) Estimating the Performance Effects of Business Groups in Emerging Markets. Strategic Management Journal, 22, 45-74. http://dx.doi.org/10.1002/1097-0266(200101)22:1<45::AID-SMJ147>3.0.CO;2-F

[32] Schumpeter, J.A. (1950) Capitalism, Socialism, and Democracy. 3rd Edition, Harper and Row, New York.

[33] Culbertson, J.D. (1985) Econometric Tests of the Market Structural Determinants of R\&D Investment: Consistency of Absolute and Relative Firm Size Models. The Journal of Industrial Economics, 34, 101-108. http://dx.doi.org/10.2307/2098485

[34] Nelson, R.R. (1959) The Simple Economics of Basic Scientific Research. Journal of Political Economy, 67, $297-306$. http://dx.doi.org/10.1086/258177

[35] Cohen, W.M. and Klepper, S. (1992) The Anatomy of Industry R\&D Intensity Distributions. The American Economic Review, 82, 773-799.

[36] Boulding, W. and Staelin, R. (1995) Identifying Generalizable Effects of Strategic Actions on Firm Performance: The Case of Demand-Side Returns to R\&D Spending. Marketing Science, 14, G222-G236. http://dx.doi.org/10.1287/mksc.14.3.G222 